\title{
Biodiversity projects face funding challenge
}

London. The principal United Nations agency responsible for funding environmental programmes - including environmental research - has had to reduce its support for biodiversity projects partly because of a lack of high-quality applications, particularly from developing countries.

Last year, the agency, known as the Global Environment Facility (GEF), awarded $\$ 23$ million for biodiversity projects, $\$ 42$ million less than in 1995 . During the previous four years, in comparison, biodiversity activities were awarded on average $\$ 80$ million each year by the GEF.

Both government representatives responsible for overseeing the UN biodiversity convention and scientists working in the area have begun to raise the issue. According to one government delegate to the biodiversity convention, concern is also mounting among members of the GEF's governing council. "There is enough money," he says. "There are just not enough quality proposals."

Stephen Blackmore, keeper of botany at the Natural History Museum in London, says that developing countries are caught in a bind. The GEF's guidelines imply that projects should be initiated by countries themselves. But this handicaps developing countries, whose scientists may have diffi- culty in preparing acceptable research proposals. Blackmore believes projects should also be allowed if proposed jointly with an institution from a developed country.

Simon Owens, keeper of the herbarium at the Royal Botanic Gardens at Kew in London, agrees, and says there is considerable willingness on the part of research organizations, such as his own, to contribute to technology transfer. "We are not into being colonial any more," he says.

Mario A. Ramos, a senior environmental specialist with the GEF in Washington DC, accepts that the reduction in take-up of biodiversity funds can be partly blamed on the lack of expertise in developing countries to prepare effective projects. But he says that he expects this situation to change as more countries complete their 'biodiversity action plans', in which signatories to the convention identify national priorities in biodiversity conservation and research.

Ramos also points out that there is no bar to nongovernmental organizations jointly proposing projects with countries, and that several - including Kew Gardens - are already involved with technical management and assistance. He adds that many factors help to account for the shortfall in biodiversity proposals. "Quality projects take time to prepare," he says. "One of the GEF's requirements is a high degree of public participation in the planning stages. It could take up to two years for funding approval after you have solicited the views of nongovernmental organizations, local communities and the government."

The GEF was set up in 1991 to provide grants and concessional funds for projects that aim to protect the environment. The facility has 156 members, and spent $\$ 733$ million on 115 projects during its pilot phase between 1991 and 1994. In March 1994, 34 members pledged to replenish the fund with an additional $\$ 2$ billion.

GEF funds are available only to countries eligible for loans from the World Bank group of financing agencies, or technical assistance grants from the United Nations Development Programme (UNDP). In addition to climate change and biodiversity, a smaller proportion of GEF funds are also spent on projects related to international waters (12 per cent) and protection of the ozone layer (10 per cent).

GEF spending is administered by the UNDP, the UN Environment Programme (UNEP) and the World Bank. The UNDP looks after projects that involve technical assistance, while UNEP is responsible for

\section{Does yur autoated}

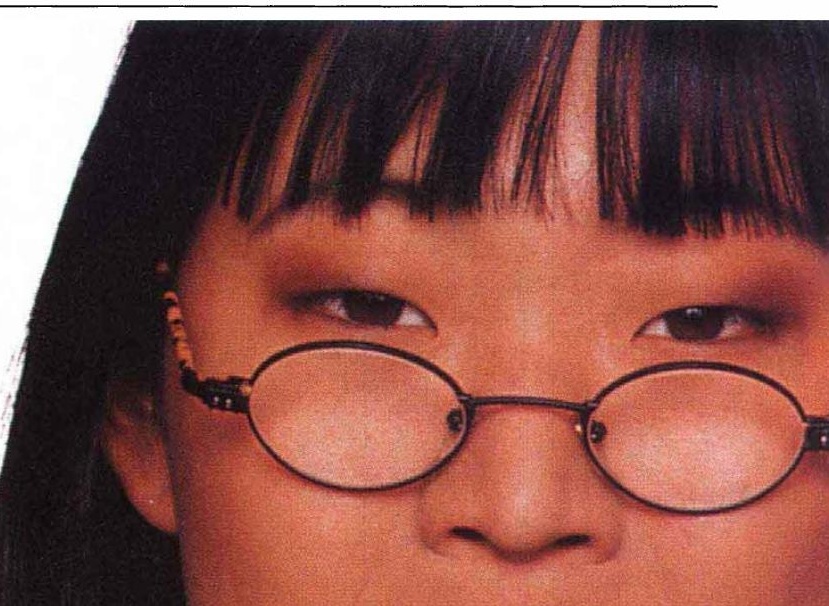




\section{IMAGE UNAVAILABLE FOR COPYRIGHT REASONS}

developed world disagree and have resisted what they consider to be attempts at 'micromanagement'. "You cannot have 160 countries all deciding on which projects to fund," says one delegate from a developed country.

A 'memorandum of understanding' between the two sides was eventually brokered at the annual conference of the parties to the convention in Argentina last November. The memorandum acknowledges that the convention is responsible for policy and strat-

Sustainable agriculture: but more research is needed.

egy. But the GEF will decide on project selection and management within agreed guidelines.

Contentious areas remain. Biodiversity environmentalist groups, some scientists and some developing countries are still not satisfied with the GEF's decision to increase its climate change budget at the expense of biodiversity. Owens of Kew Gardens says that "biodiversity is sometimes considered the poor relation to the more fashionable climate change", but is just as important.

During 1991-94, the GEF spent 45 per cent of its budget on biodiversity projects and 35 per cent on projects in areas that reduce the impact of climate change, such as power generation. During 1995 and 1996, these percentages swung to 19 and 47 per cent respectively. The GEF now plans to devote around 30 per cent of its budget to biodiversity, and 45 per cent to projects related to climate change for 1997 and 1998.

Ramos says criticism about the apparent imbalance is misplaced. Climate change projects, such as renewable energy sources, tend to be more capital-intensive than biodiversity projects, he says.

So far, he adds, GEF has provided $\$ 415$ million in biodiversity project finance for more than 71 national, regional and global projects. But, he says, it expects a greater number of biodiversity projects during the next few years - more than climate change - and is setting aside $\$ 136$ million for such projects during 1996-97.

Another controversial issue is the nature of the GEF's financing method. GEF does not fund projects in full, but only the difference - the 'incremental cost' - between the price of a project, such as a coal-fired power station, and the cost of an environmentally cleaner alternative.

Blackmore of the Natural History Museum says incremental funding is inappropriate for research proposals and feasibility studies. But Ramos counters by pointing out that GEF operates a separate fund for project analysis and feasibility studies that does not operate on the incremental cost model. Between $\$ 25,000$ and $\$ 1$ million is available to assess the feasibility of any proposal, including the conduct of relevant research.

Ehsan Masood
Does your automated DNA sequencer leave you guessing? If so, chances are it's primarily designed for high throughput sequencing. Why be uncertain of your sequencer's accuracy, when ALFexpress ${ }^{\text {Tw }}$ is providing researchers with the full genetic stories of their DNA.

\section{ATifexpress: for more accurate readings}

In the largest clinical study using automated DNA sequencing, the technology behind ALFexpress proved exceptional (see caption). That's one of many examples of ALFexpress offering unrivaled accuracy during automated confirmatory sequencing. Further, its readings are so accurate that ALFexpress can unambiguously identify heterozygous point mutations-as proven in many clinical research applications, such as analysis of tumor genes and high-resolution HLA typing. What's more, Pharmacia Biotech has dedicated software programs to support these applications.

For the full story, call us: I (800) 526-3593 from the U.S.; +8I (0)3 3492 6949 from Japan; or $+46(0) 18165000$ from Europe and the rest of the world. Or visit us on the Internet: http://mww.biotech.pharmacia.se.

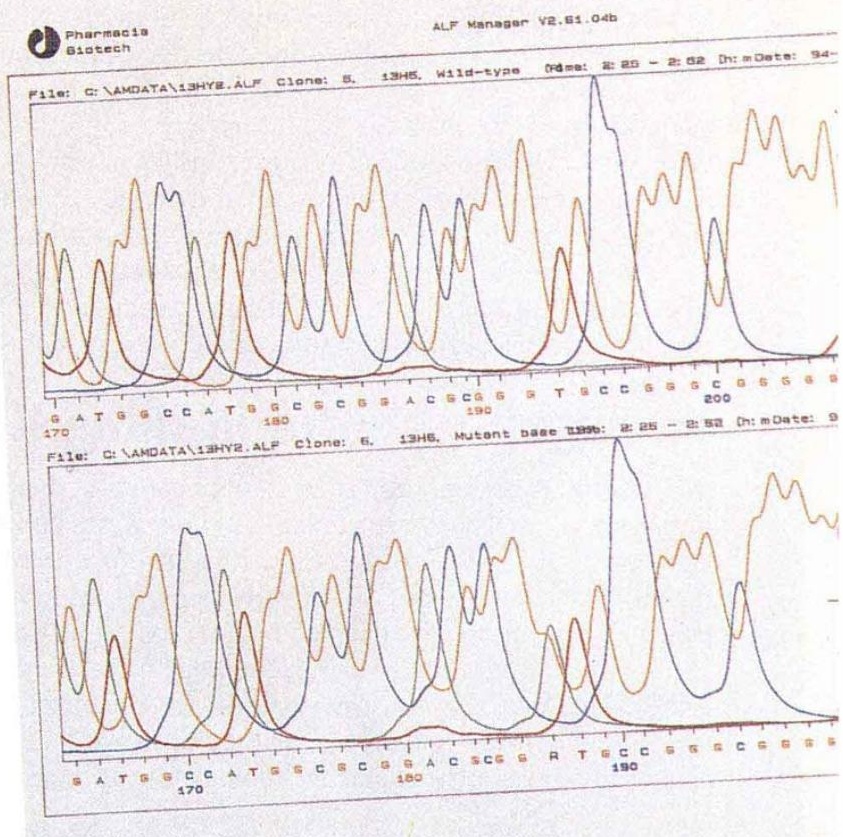

The $p 53$ gene from 316 breast cancer patients was sequenced using ALF automated sequencing technology. (Bergh J., Norberg, T., Sjögren, S., Lindgren A., Holmberg, L. "Complete Sequencing of the p53 Gene ..." Nature Medicine 1995; 10:1029-1034.) 